\title{
Gas-phase oxidation of reactive organometallic ions
}

Anuj Joshi, Sofia Donnecke, Ori Granot, Dongju Shin, Scott Collins, I Paci and J. Scott McIndoe*

Department of Chemistry, University of Victoria, PO Box 1700 STN CSC, Victoria, BC V8W 2Y2, CANADA. Fax: +1 (250) 721-7147; Tel: +1 (250) 721-7181; E-mail: mcindoe@uvic.ca

\begin{abstract}
Analysis of highly reactive compounds at very low concentration in solution using electrospray ionization mass spectrometry requires the use of exhaustively purified solvents. It has generally been assumed that desolvation gas purity needs to be similarly high, and so most chemists working in this space have relied upon high purity gas. However, the increasingly competitiveness of nitrogen generators, which provide gas purity levels that vary inversely with flow rate, prompted an investigation of the effect of gas-phase oxygen on the speciation of ions. For moderately oxygen sensitive species such as phosphines, no gas-phase oxidation was observed. Even the most reactive species studied, the reduced titanium complex $\left[\mathrm{Cp}_{2} \mathrm{Ti}(\mathrm{NCMe})_{2}\right]^{+}\left[\mathrm{ZnCl}_{3}\right]^{-}$and the olefin polymerization precatalyst $\left[\mathrm{Cp}_{2} \mathrm{Zr}(\mu-\mathrm{Me})_{2} \mathrm{AlMe}_{2}\right]^{+}$ $\left[\mathrm{B}\left(\mathrm{C}_{6} \mathrm{~F}_{5}\right)_{4}\right]^{-}$, only exhibited detectable oxidation when they were rendered coordinatively unsaturated through in-source fragmentation. Computational chemistry allowed us to find the most plausible pathways for the observed chemistry in the absence of observed intermediates. The results provide insight into the gas-phase oxidation of reactive species and should assure experimentalists that evidence of significant oxidation is likely a solution rather than a gas-phase process, even when relatively low-purity nitrogen is used for desolvation.
\end{abstract}

\section{Graphical abstract}

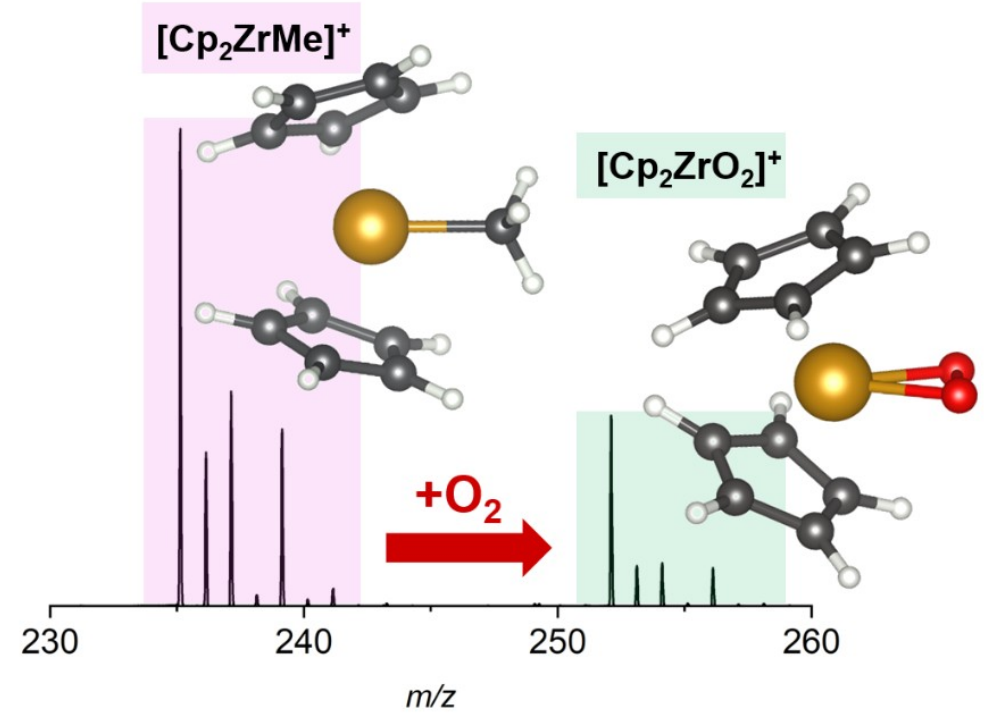




\section{Introduction}

Electrospray ionization mass spectrometry (ESI-MS) is a useful tool to study reactions involving transition metal complexes. ${ }^{1-3}$ As this technique is very sensitive and operates best at low (charged) analyte concentrations $(<\mu \mathrm{M})$, the air- and moisture sensitivity of many transition metal complexes requires rigorous precautions to remove air and moisture dissolved in solvents or other reagents to obtain meaningful results. ${ }^{4}$ An inert atmosphere glove-box, when interfaced to the mass spectrometer, using flexible PEEK or PTFE tubing and an air tight seal, protects analyte solutions from atmospheric contamination during transit to the source compartment of the mass spectrometer. ${ }^{5}$

During the electrospray ionization process, charged droplets form and rapidly evaporate under the influence of an inert desolvation gas (nitrogen is typically used) to produce gas phase ions. These ions are deflected towards the mass spectrometer and accelerated using a modest voltage bias (cone voltage) through a (source) compartment operated typically from atmospheric to 0.1-1.0 mm pressures. ${ }^{6}$ During this transit the ions encounter desolvation gas and other volatile materials such as solvent or contaminants like water and oxygen. The desolvation gas is rarely completely pure: $99.999 \%$ (5.0) nitrogen still contains as much as 3 ppm oxygen and 5 ppm water, and those contaminants are continually introduced into the mass spectrometer. If the source compartment is significantly contaminated, undesired ion-molecule reactions may occur during transit to the high vacuum regions of the instrument. Ion-molecule reactions can also occur in the collision cell of a tandem mass spectrometer, as this relatively high-pressure region can accumulate neutral molecules (especially water) during MS/MS experiments.

Nitrogen generators are becoming increasingly popular as a gas source for mass spectrometric applications. ${ }^{7}$ Nitrogen generators supply nitrogen on demand and save a significant amount of money in labs that require continuous $\mathrm{N}_{2}$ supply. Those advantages aside, an important query remains as to whether this source of $\mathrm{N}_{2}$ is of high enough purity for air sensitive chemistry. ${ }^{8}$ We are intrigued as to whether the reactive ions found in transition metal chemistry might be used to advantage to gauge experimental conditions within the mass spectrometer, and whether changes in desolvation gas or collision gas purity had demonstrable effects on the mass spectra of these species. In previous work, we have reported anecdotal evidence of impurity (mainly oxygen and water) problems during ESI-MS analysis where the source(s) were not conclusively established. Examples in the case of oxygen include phosphine oxidation during $\mathrm{Rh}(\mathrm{I})$ - or $\mathrm{Pd}(0)$ mediated catalysis. ${ }^{9,10}$ In the latter case, we established that oxygen dissolved in solution was responsible for this facile process. In other work we have mentioned the sensitivity of aluminoxane anions ${ }^{11-13}$ and zirconocene methyl cations ${ }^{4,14}$ towards both oxygen and water, obviously in solution, but also in the gas phase with reactive ions generated through in-source CID. ${ }^{4}$ We have also studied the reaction of a reduced titanocene complex (which is used as an indicator for atmospheric oxygen) ${ }^{15}$ with $\mathrm{O}_{2} \cdot{ }^{16}$

We wondered whether any of this chemistry might form the basis for sensitively detecting impurity problems associated with operation of the mass spectrometer, as opposed to solution contamination, where rigorous drying and deoxygenation protocols usually suffice. In this paper 
we focus on the use of reactive titanium and zirconium complexes as indicators for both gas phase oxygen, and in the latter case, also water.

\section{Results and discussion}

Although phosphine oxidation mediated by atmospheric $\mathrm{O}_{2}$ can be difficult, ${ }^{17}$ the transitionmetal-mediated process is quite pernicious. ${ }^{18-20}$ It typically involves oxidation of the metal to form a metal-peroxo complex, followed by oxidation of additional phosphine ligand by that complex. ${ }^{21}$ In our earlier work, we used air (i.e. $20 \% \mathrm{O}_{2}$ ) to mediate pressurized sample infusion $^{10,22}$ of charge-tagged, $\operatorname{Pd}(0)$ phosphine complexes to study this oxidation process. ${ }^{9,10}$ Exploratory studies revealed that this process was unsuited to monitor e.g. gas purity using either $99.99 \%$ or $99.999 \%$ purity $\mathrm{N}_{2}$ as desolvation gas; only deliberate introduction of air in contact with the solution as in the earlier work led to detectable oxidation (see Supporting Information S1).

Similarly, many metal complexes are known to reversibly or irreversibly react with $\mathrm{O}_{2}$ to form peroxo complexes. A well-studied system based on 16 e $\left[C p^{\star}(L)_{2} R u\right]^{+}(L=$ phosphine $)$ complexes are directly suited to ESI-MS studies, as they are charged and strongly bind both $\mathrm{N}_{2}$ and $\mathrm{O}_{2}$ in solution to form 18 electron complexes. ${ }^{23}$ While both of these 18 electron ions could be detected in exploratory experiments, the $\mathrm{N}_{2}$ and $\mathrm{O}_{2}$ ligands were labile in the gas phase, as well as coordinated triphenylphosphine, even at low cone voltages, complicating the interpretation of the results. ${ }^{24}$ From these studies it was clear that any solution phase reaction would have to be effectively diffusion controlled, and irreversible for the reaction to be of use to monitor conditions within the mass spectrometer. Based on our earlier work, we focused on the use of reduced titanocene(III) complexes and cationic zirconocene(IV) alkyls as indicators for oxygen and water.

The ESI-MS of $\left[\mathrm{Cp}_{2} \mathrm{Ti}(\mathrm{NCMe})_{2}\right]^{+}\left[\mathrm{ZnCl}_{3}\right]^{-}$prepared from $\mathrm{Cp}_{2} \mathrm{TiCl}_{2}$ with $\mathrm{Zn}$ in acetonitrile under "normal" (using 99.999\% purity $\mathrm{N}_{2}$ from a cylinder as a source of cone and desolvation gas) conditions results in a spectra that is dominated by $\left[\mathrm{Cp}_{2} \mathrm{Ti}(\mathrm{NCMe})_{n}\right]^{+}(n=1$ or $2, \mathrm{~m} / \mathrm{z} 219$ and 260) ions (Figure 1a). When the source of $\mathrm{N}_{2}$ was changed to generator $\mathrm{N}_{2}$ we saw two additional low abundance species (Figure $1 b$ ), readily assigned to $\left[\mathrm{Cp}_{2} \mathrm{TiO}_{2}\right]^{+}(\mathrm{m} / \mathrm{z} 210)$ and $\left[\mathrm{Cp}_{2} \mathrm{Ti}\left(\mathrm{O}_{2}\right)(\mathrm{NCMe})\right]^{+}(\mathrm{m} / \mathrm{z} 251)$ based on isotope pattern, $\mathrm{m} / \mathrm{z}$ ratio and MS/MS behavior. 


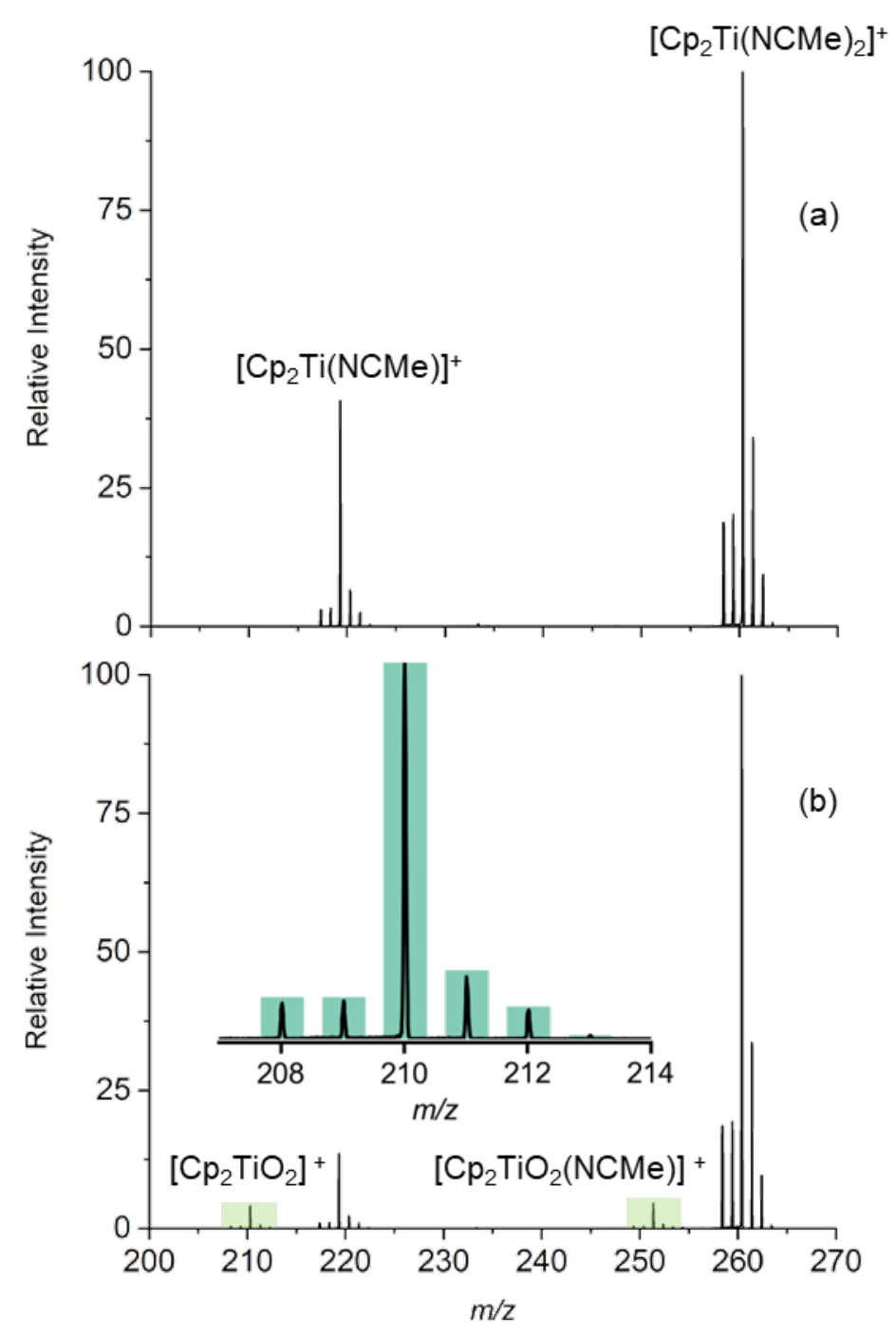

Figure 1: The $\left[\mathrm{Cp}_{2} \mathrm{Ti}(\mathrm{NCMe})_{2}\right]^{+}$system with $\mathrm{N}_{2}$ supply from (a) 5.0 purity $\mathrm{N}_{2}$ cylinder and (b) Generator. Inset in $2 \mathrm{~b}$ shows the expected (highlighted) and experimental isotopic pattern of the 210 species.

The MS/MS spectrum of $\left[\mathrm{Cp}_{2} \mathrm{Ti}\left(\mathrm{O}_{2}\right)(\mathrm{NCMe})\right]^{+}$shows acetonitrile ligand loss to form $\left[\mathrm{Cp}_{2} \mathrm{TiO}_{2}\right]^{+}$ (Supporting Information S2). In the same vein, the MS/MS of $\left[\mathrm{Cp}_{2} \mathrm{TiO}_{2}\right]^{+}$shows the loss of $\mathrm{O}_{2}$ to form $\left[\mathrm{Cp}_{2} \mathrm{Ti}^{+}\right.$(Supporting Information S3). We propose that the $\left[\mathrm{Cp}_{2} \mathrm{TiO}_{2}\right]^{+}$species is formed via the substitution of neutral acetonitrile ligands with $\mathrm{O}_{2}$. This process may or may not be accompanied by oxidation of the metal centre, i.e. $\left[\mathrm{Cp}_{2} \mathrm{TiO}_{2}\right]^{+}$can be formulated either as $\left[\mathrm{Cp}_{2} \mathrm{Ti}(\mathrm{III})\left(\eta^{2}-\mathrm{O}_{2}\right)\right]^{+}$or as $\left[\mathrm{Cp}_{2} \mathrm{Ti}(\mathrm{IV})\left(\eta^{2}-\mathrm{O}_{2}^{--}\right)\right]^{+}$where in the latter ion, oxygen has been reduced to the superoxide radical anion.

To further support our claim that trace amounts of $\mathrm{O}_{2}$ present in the generator $\mathrm{N}_{2}$ reacts with the $\mathrm{Ti}$ species we performed an experiment in which the purity of $\mathrm{N}_{2}$ produced was changed. Since the nitrogen purity of these generators is flow rate dependent ${ }^{25,26}$ we changed the total rate of $\mathrm{N}_{2}$ produced at the generator, while maintaining constant cone and desolvation gas flow rates at 
the instrument (see Experimental Section for details). The ratio of the oxidized to un-oxidized species was plotted against the total flow rate of $\mathrm{N}_{2}$ gas (Figure 2). It was observed that this ratio increases as the flow rate increases (as the purity of $\mathrm{N}_{2}$ decreases).

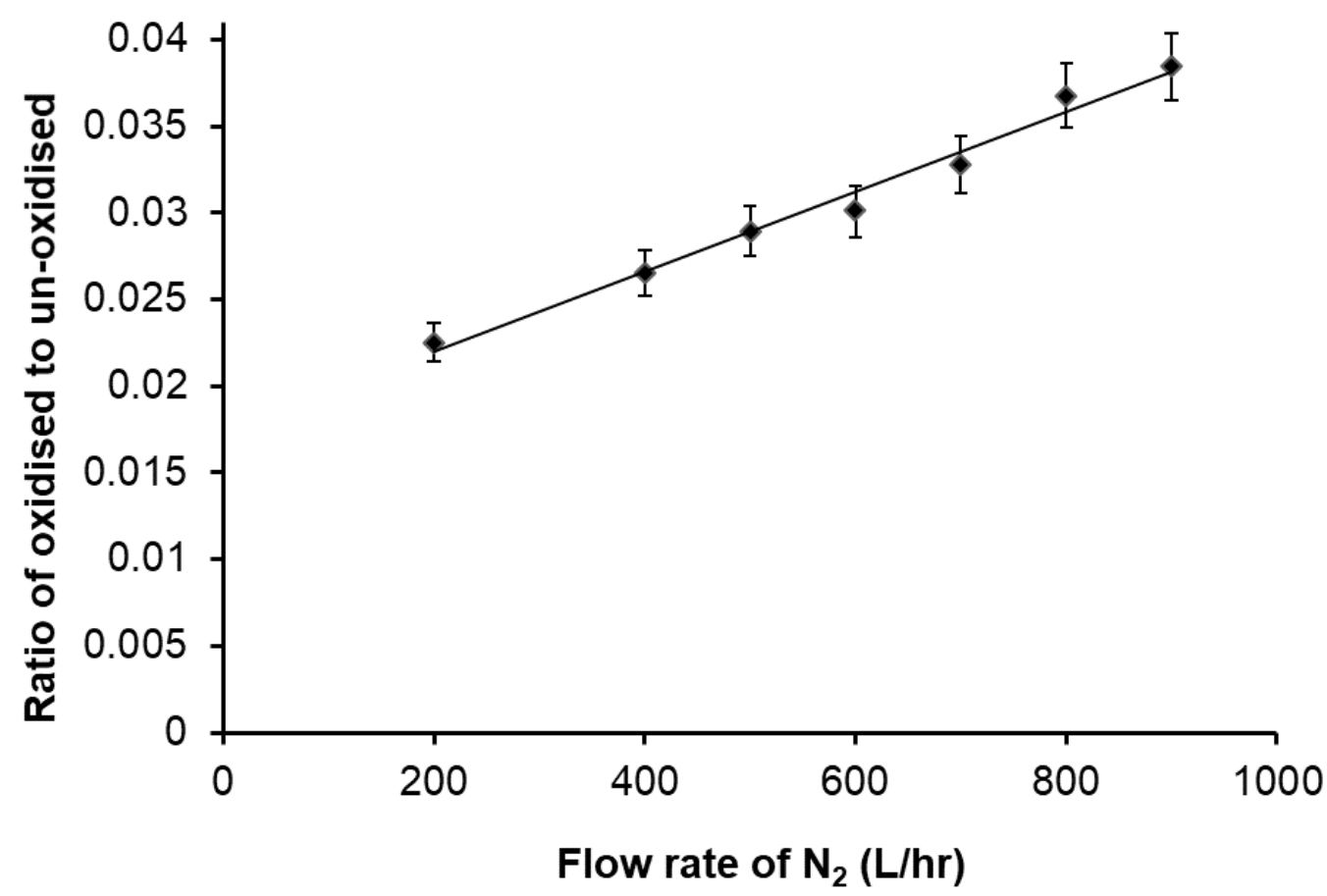

Figure 2: The ratio of oxidized species to unoxidized species plotted against flow rate with the error bar showing 95 percent confidence level in the measurements.

To better understand the observed oxidation reaction, we studied it computationally. ${ }^{27}$ Mass spectrometric results (Figure 1 ) suggest that $\left[\mathrm{Cp}_{2} \mathrm{Ti}(\mathrm{NCMe}]^{+}\right.$is the primary source of the oxygen-containing complex $\left[\mathrm{Cp}_{2} \mathrm{TiO}_{2}\right]^{+}$, given its reduced presence in Figure 1 (b) and its status as the only unsaturated species present. $A b$ initio molecular dynamics (AIMD) simulations at $300 \mathrm{~K}$ of $\left[\mathrm{Cp}_{2} \mathrm{Ti}(\mathrm{NCMe})\right]^{+}+\mathrm{O}_{2}$ and $\left[\mathrm{Cp}_{2} \mathrm{Ti}(\mathrm{NCMe})_{2}\right]^{+}+\mathrm{O}_{2}$ support this hypothesis, as the titanium in the $\left[\mathrm{Cp}_{2} \mathrm{Ti}(\mathrm{NCMe})_{2}\right]^{+}$complex is inert to $\mathrm{O}_{2}$ while the $\mathrm{Ti}$ of $\left[\mathrm{Cp}_{2} \mathrm{Ti}(\mathrm{NCMe})\right]^{+}$readily binds to $\mathrm{O}_{2}$ (see SI, inert_O2Ti.MOV and O2Ti.MOV).

As the concerted pathway from $\left[\mathrm{Cp}_{2} \mathrm{Ti}(\mathrm{NCMe})_{2}\right]^{+}$to $\left[\mathrm{Cp}_{2} \mathrm{TiO}_{2}(\mathrm{NCMe})\right]^{+}$or $\left[\mathrm{Cp}_{2} \mathrm{TiO}_{2}\right]^{+}$is not likely, we calculated energy diagrams for two possible mechanisms, both involving the initial dissociation of $\left[\mathrm{Cp}_{2} \mathrm{Ti}(\mathrm{NCMe})_{2}\right]^{+}$to $\left[\mathrm{Cp}_{2} \mathrm{Ti}(\mathrm{NCMe})\right]^{+}:$a concerted mechanism wherein $\mathrm{O}_{2}$ replaces $\mathrm{CH}_{3} \mathrm{CN}$ as a ligand, and a stepwise mechanism where the second $\mathrm{O}_{2}$ binds in a monodentate fashion prior to loss of the second $\mathrm{CH}_{3} \mathrm{CN}$ and $\mathrm{O}_{2}$ reorientation to $\mathrm{n}^{2}-\mathrm{O}_{2}$ (Figure 3). Changes in energy for the different steps along the reaction paths are reported, at various levels of theory (SI Table 1). 


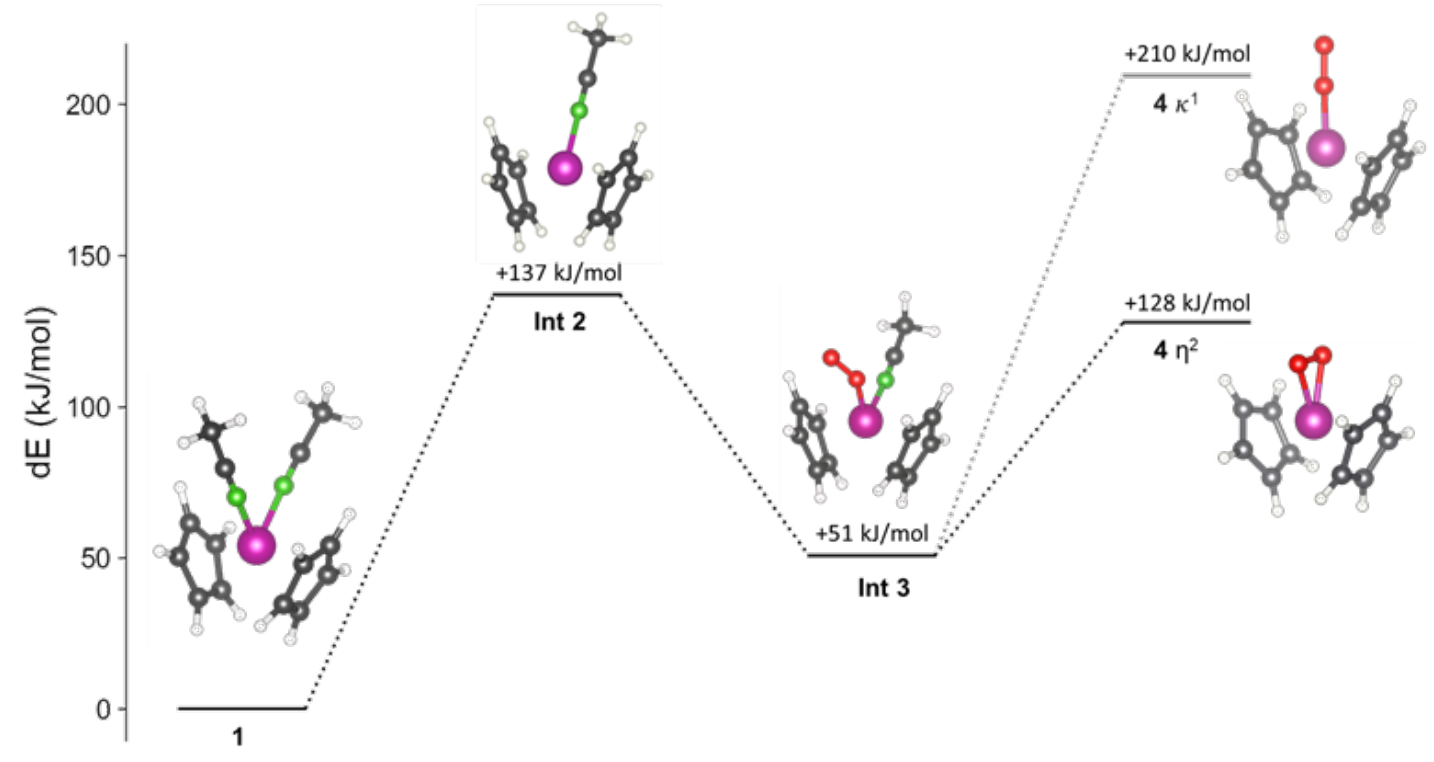

Figure 3. The $\left[\mathrm{Cp}_{2} \mathrm{Ti}(\mathrm{NCMe})_{2}\right]^{+}+\mathrm{O}_{2}$ reaction pathway calculated with SIESTA (UPBE-D2). In the stepwise mechanism for Ti ligand exchange, the reaction pathway can be modelled as a series of bond association/dissociation steps $\mathbf{1} \rightarrow \mathbf{2} \rightarrow \mathbf{3} \rightarrow \mathbf{4}$. All steps are single bond dissociation or association steps, and are therefore barrierless. Although a concerted pathway from $\mathbf{2}$ to $\mathbf{4}$ may occur when the $\mathrm{Ti} / \mathrm{O}_{2}$ bond forms as the $\mathrm{CH}_{3} \mathrm{CN}$ breaks away, there is no saddle point along the PES because the minimum energy of this transition state results in structure 3.

Energy differences obtained from the PBE-D2/DZP methodology in SEISTA were consistent with higher-level B2PLYP-D3 calculations, thus validating the SIESTA approach for these systems. Loss of the first acetonitrile ligand in the first step destabilizes the complex, creating the opportunity for attack from the $\mathrm{O}_{2}$ molecules present in the gas phase. Species 2, 3, and 4 were all observed in the mass spectrometry experiments. The most stable structure of $\mathbf{4}$ had $\mathrm{O}_{2}$ in an $\eta^{2}$ configuration, replacing both monodentate $\mathrm{CH}_{3} \mathrm{CN}$ ligands (see Figure 3). The $\mathbf{2} \rightarrow \mathbf{3} \rightarrow$ 4 pathway is a sequence of bond dissociation and association steps and thus barrierless, and the lowest energy pathway in the computational model. However, higher-energy species are accessible in the ESI-MS setup, making a concerted mechanism for the $\mathbf{2} \rightarrow \mathbf{4}$ pathway viable. The possibility of a monodentate binding by $\mathrm{O}_{2}$ was considered in the product 4 , in addition to the bidentate mode. The $\mathrm{K}^{1}-\mathrm{O}_{2}$ form is less stable than the $\eta^{2}-\mathrm{O}_{2}$ binding mode. This is reflected in the HOMO geometries of the two species. Greater overlap between the metal center and two of the lone pairs orbitals of the bidentate $\mathrm{O}_{2}$ molecule is evidenced in the HOMO of the $\eta^{2}-\mathrm{O}_{2}$ complex (Figure 4b), compared to the single lone-pair participating in binding of the $\mathrm{K}^{1}-\mathrm{O}_{2}$ mode (see Figure 4a). 

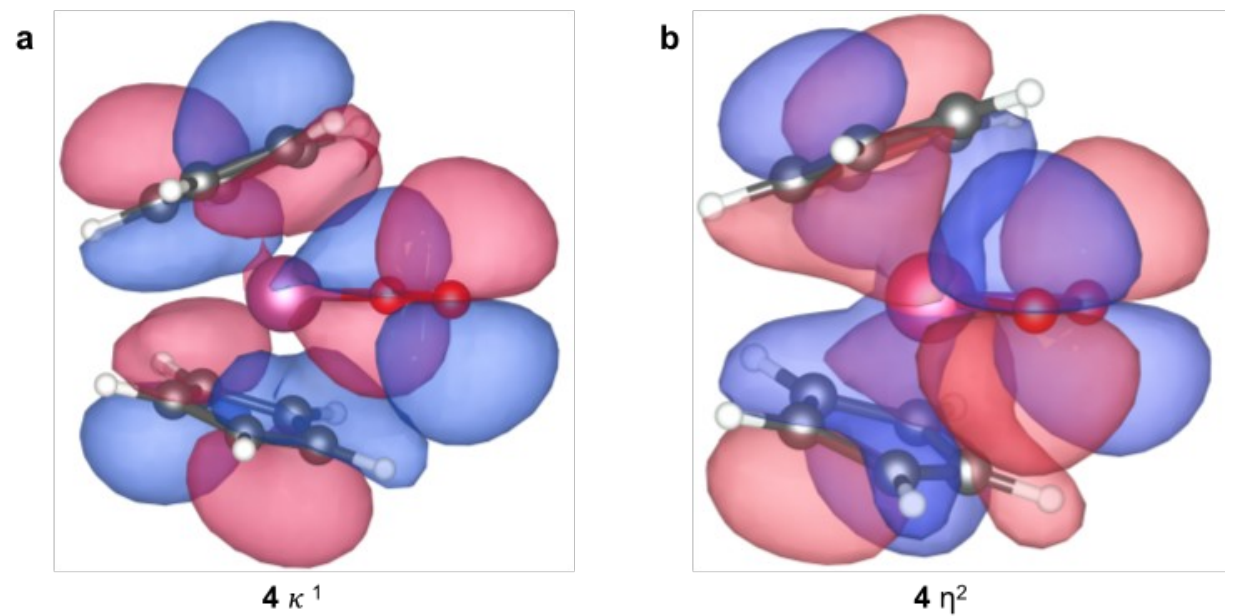

Figure 4. $\mathrm{HOMO}$ in (a) monodentate and (b) bidentate bound $\mathrm{O}_{2}$ in $\left[\mathrm{Cp}_{2} \mathrm{TiO}_{2}\right]^{+}$.

The final reactive system that we studied involved the ion $\left[\mathrm{Cp}_{2} \mathrm{Zr}(\mu-\mathrm{Me})_{2} \mathrm{AlMe}_{2}\right]^{+}(\mathrm{m} / \mathrm{z} 307)$ which can be conveniently generated in situ from $\mathrm{Cp}_{2} \mathrm{ZrMe}_{2}$, excess $\mathrm{AlMe}_{3}$ and $\left[\mathrm{Ph}_{3} \mathrm{C}\right]\left[\mathrm{B}\left(\mathrm{C}_{6} \mathrm{~F}_{5}\right)_{4}\right]$ in fluorobenzene solution. ${ }^{28,29}$ As discussed elsewhere, the appearance of the mass spectrum of this ion is sensitive to cone voltage (in-source fragmentation via collision-induced dissociation), and loss of $72 \mathrm{Da}\left(\mathrm{Me}_{3} \mathrm{Al}\right)$ in the gas phase via CID, either in source or the collision cell is facile..$^{4,14}$ The resulting (gas phase) 14 electron ion $\left[\mathrm{Cp}_{2} Z \mathrm{ZMe}\right]^{+}(\mathrm{m} / \mathrm{z} 235)$ is known to be exceptionally reactive towards a variety of gaseous species ${ }^{30-33}$ but its reaction with $\mathrm{O}_{2}$ or water has not been systematically studied. When these studies were initiated using generator $\mathrm{N}_{2}$, the mass spectrum became more complicated. Instead of the normal spectrum consisting of just $\left[\mathrm{Cp}_{2} \mathrm{Zr}(\mu-\mathrm{Me})_{2} \mathrm{AlMe}\right]^{+}$and $\left[\mathrm{Cp}_{2} \mathrm{ZrMe}\right]^{+}$(Figure $5 \mathrm{a}$ ), a spectrum at the same cone voltage (8 V) revealed new ions at $m / z 252,255$, and 270, as well as $\left[\mathrm{Cp}_{2} \mathrm{Zr}(\mu-\mathrm{Me})_{2} \mathrm{AlMe}_{2}\right]^{+}$(Figure 5b). Only trace amounts of $\left[\mathrm{Cp}_{2} \mathrm{ZrMe}\right]^{+}$were present, and peaks at $\mathrm{M}+2$ were observed indicating hydrolysis (exchange of $\mathrm{Me}$ for $\mathrm{OH}){ }^{4}$ 


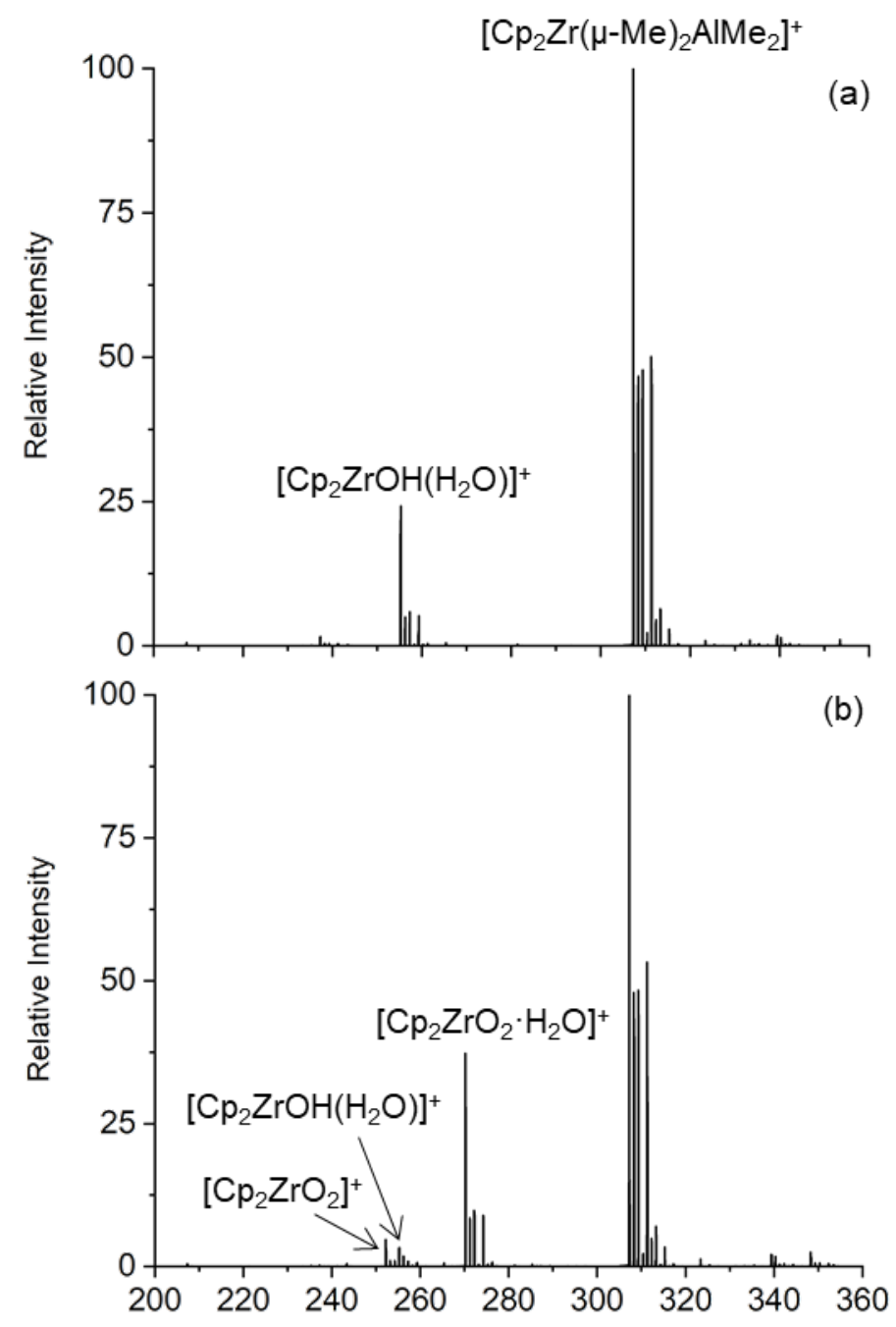

Figure 5 - Positive ion mass spectrum of $\left[\mathrm{Cp}_{2} \mathrm{ZrMe}_{2} \mathrm{AlMe}_{2}\right]\left[\mathrm{B}\left(\mathrm{C}_{6} \mathrm{~F}_{5}\right)_{4}\right](0.25 \mathrm{mM}$ in PhF, cone voltage $8 \mathrm{~V}$ ) generated using a) $99.999 \% \mathrm{~N}_{2}$ from a cylinder b) $\mathrm{N}_{2}$ from the generator.

MS/MS studies on $\mathrm{m} / \mathrm{z} 255$ revealed that it fragmented by loss of $18 \mathrm{Da}\left(\mathrm{H}_{2} \mathrm{O}\right)$ to furnish $\left[\mathrm{Cp}_{2} \mathrm{ZrOH}\right]^{+}$with $\mathrm{m} / \mathrm{z} 237$ which loses at higher energy $66 \mathrm{Da}$ (cyclopentadiene) to furnish $[\mathrm{CpZrO}]^{+}$with $\mathrm{m} / \mathrm{z}$ 171. Thus the ion with $\mathrm{m} / \mathrm{z} 255$ is evidently $\left[\mathrm{Cp}_{2} \mathrm{ZrOH}\left(\mathrm{H}_{2} \mathrm{O}\right)\right]^{+}$and indicates trace water in the nitrogen gas supply. After venting the spectrometer (which results in exhaustive flushing of the interior with $\mathrm{N}_{2}$ ), re-establishing vacuum, and conditioning the MCP detector, subsequent spectra obtained using $5.0 \mathrm{~N}_{2}$ showed no signs of oxidation or hydrolysis, indicating that the likely source of water was the instrument itself. 




Figure 6: The $\left(\left[\mathrm{Cp}_{2} \mathrm{Zr}(\mu-\mathrm{Me})_{2} \mathrm{AlMe}\right]^{+}\right)$system with $\mathrm{N}_{2}$ supply from (a) 5.0 purity $\mathrm{N}_{2}$ cylinder and (b) generator $\mathrm{N}_{2}$. Inset in $2 \mathrm{~b}$ shows the expected (bars) and experimental (line) isotope pattern of $\left[\mathrm{Cp}_{2} \mathrm{ZrO}_{2}\right]^{+}$.

The remaining ions in Figure (5b) have $\mathrm{m} / \mathrm{z} 252$ and 270 . Since the difference in mass between these two ions is also $18 \mathrm{Da}$, it is reasonable to assign the latter as the aquo complex of the former. In agreement with this hypothesis, $\mathrm{m} / \mathrm{z} 270$ was observed with vastly reduced intensity following venting and flushing of the instrument with $\mathrm{N}_{2}$ on subsequent start-up. However, the ion with $\mathrm{m} / \mathrm{z} 252$ persisted as long as generator gas was supplied to the instrument (Figure 6b). We suspected this ion was $\left[\mathrm{Cp}_{2} \mathrm{ZrO}_{2}\right]^{+}$by analogy to the results obtained using the reduced titanocene complex with oxygen (vide supra). The ion has the expected isotope pattern, correct $\mathrm{m} / \mathrm{z}$ ratio and a consistent MS/MS product ion spectrum (see Supporting Information S4). However, $\left[\mathrm{Cp}_{2} \mathrm{ZrO}_{2}\right]^{+}$is not the expected product of oxidation of $\left[\mathrm{Cp}_{2} \mathrm{Zr}(\mu-\mathrm{Me})_{2} \mathrm{AlMe}_{2}\right]^{+}$in solution; rather, $\mathrm{Zr}$ alkoxides are invariably produced, at least with neutral zirconocene dialkyls. ${ }^{34}$ The stereochemistry of this oxidation process proceeded with $50 \%$ racemization and $50 \%$ retention 
of stereochemistry. The authors invoked homolytic cleavage of a $\mathrm{Zr}-\mathrm{R}$ bond as the first step in this process to account for the racemization (Equation 1). The second step involved recombination of these radicals to form a metal peroxide intermediate.

$$
\mathrm{Cp}_{2} \mathrm{ZrR}_{2}+\mathrm{O}_{2} \rightarrow \mathrm{Cp}_{2} \mathrm{Zr}(\mathrm{R}) \mathrm{O}_{2} \bullet+\mathrm{R} \bullet \quad \text { Equation } 1
$$

In the gas phase, such recombination is much less plausible, and so one might expect to form $\left[\mathrm{Cp}_{2} \mathrm{ZrO}_{2}\right]^{+}$via initial reaction of a cationic alkyl with $\mathrm{O}_{2}$.

The hydrolytic sensitivity of $\left[\mathrm{Cp}_{2} \mathrm{ZrMe}\right]^{+}$has been mentioned in several previous papers. ${ }^{30,35}$ As shown above, when the instrument is contaminated with both water and oxygen, ions formed by both processes are observed. Normally such ions are characterized by $\mathrm{MS}^{\mathrm{n}}$ studies, and our instrument is capable of both $\mathrm{MS}^{2}$ and pseudo-MS $\mathrm{MS}^{3}$ experiments (the latter requires in source fragmentation of the precursor ion).

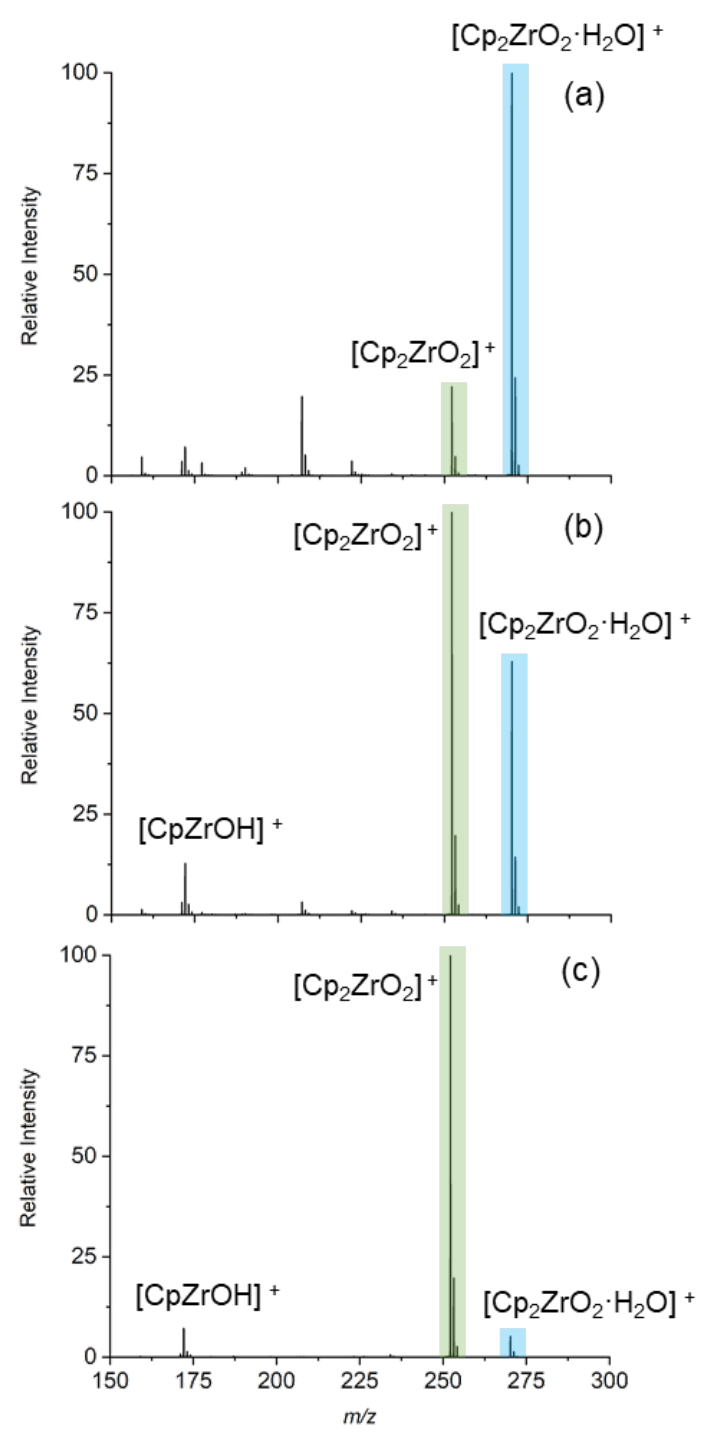

Figure 7: The MSMS of $\left[\mathrm{Cp}_{2} \mathrm{ZrO}_{2}\right]^{+}(\mathrm{m} / \mathrm{z} 252$, green) species with argon collision gas at (a) high (b) medium and (c) low collision cell pressures to form $\left[\mathrm{Cp}_{2} \mathrm{ZrO}_{2}\left(\mathrm{H}_{2} \mathrm{O}\right)\right]^{+}$(blue). 
When we attempted to characterize $\left[\mathrm{Cp}_{2} \mathrm{ZrO}_{2}\right]^{+}$via this process, we saw both the expected ion and one $18 \mathrm{Da}$ (water) higher in mass form after turning on the collision gas (Ar at 15 psig with collision voltage $=2 \mathrm{~V}$ ). The effect is completely reversible and the ratio of the $\left[\mathrm{Cp}_{2} \mathrm{ZrO}_{2}\right]^{+}$and the $\left[\mathrm{Cp}_{2} \mathrm{ZrO}_{2}\left(\mathrm{H}_{2} \mathrm{O}\right)\right]^{+}$ions was largely invariant with time. Similar results were obtained with other ions (see Supporting Information S5). Elsewhere we used helium as the collision gas to minimize this problem ${ }^{14}$ but this solution is limited in scope as any collisions are necessarily reduced in energy, which is a problem for ions which are resistant to fragmentation. Here, we found that reduction of the Ar pressure largely eliminates hydrolysis in the collision cell (compare Figure 7a vs 7b and 7c). Low argon pressures were used in all subsequent work for ions requiring MS/MS characterization. Evidently, the source of the water in these experiments is either the $5.0 \mathrm{Ar}$ gas in use $\left(\leq 3 \mathrm{ppm} \mathrm{H}_{2} \mathrm{O}\right)$, and/or adsorbed water in the collision cell which is dislodged from the inner surfaces during analysis.

As $\left[\mathrm{Cp}_{2} \mathrm{ZrMe}\right]^{+}$forms from $\left[\mathrm{Cp}_{2} \mathrm{Zr}(\mu-\mathrm{Me})_{2} \mathrm{AlMe}\right]^{+}$and we believe that the oxidized product is formed by way of a reaction of $\mathrm{O}_{2}$ with $\left[\mathrm{Cp}_{2} \mathrm{ZrMe}\right]^{+}$, spectra were recorded at two different cone voltage (Figure 8).
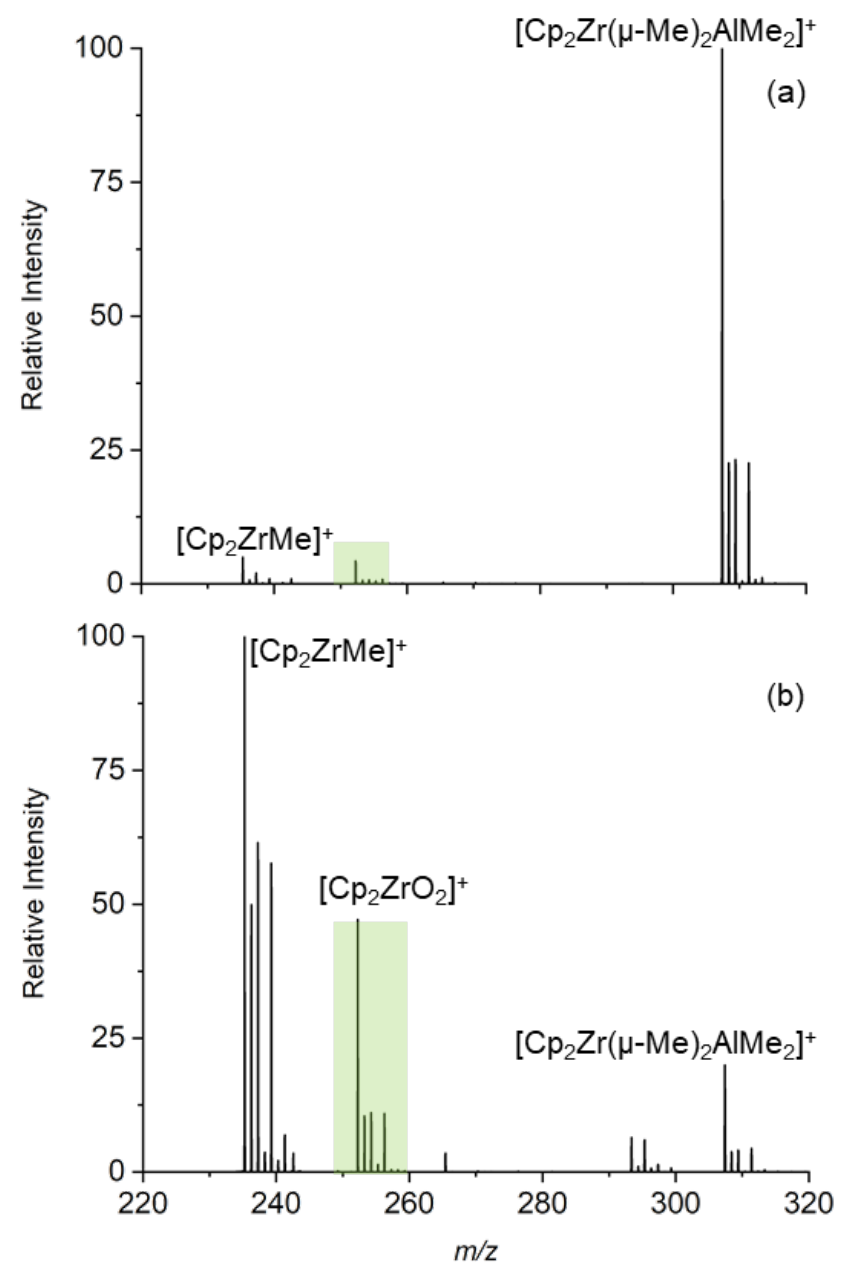

Figure 8: The $\left[\mathrm{Cp}_{2} \mathrm{Zr}(\mu-\mathrm{Me})_{2} \mathrm{AIMe}\right]^{+}$system with $\mathrm{N}_{2}$ supply from generator at (a) $12 \mathrm{~V}$ and (b) $24 \mathrm{~V}$. 
When the cone voltage is at $12 \mathrm{~V}$ the predominant species is $\left[\mathrm{Cp}_{2} \mathrm{Zr}(\mu-\mathrm{Me})_{2} \mathrm{AlMe}_{2}\right]^{+}$but when the cone voltage is increased to $24 \mathrm{~V}$ both $\left[\mathrm{Cp}_{2} \mathrm{ZrMe}\right]^{+}$and $\left[\mathrm{Cp}_{2} \mathrm{ZrO}_{2}\right]^{+}$increase in intensity. This increased reactivity is in response to high cone voltage causing $\mathrm{Me}_{3} \mathrm{Al}$ loss, generating a vacant coordination site and increasing the internal energy of the $\left[\mathrm{Cp}_{2} \mathrm{ZrMe}\right]^{+}$ion.

In a separate experiment, cone voltage was ramped up to $100 \mathrm{~V}$ and traces from individual ions were plotted (see Supporting Information S6). We can see that as the cone voltage increases, the $\left[\mathrm{Cp}_{2} \mathrm{Zr}(\mu-\mathrm{Me})_{2} \mathrm{AlMe}\right]^{+}$ion decreases in intensity and both $\left[\mathrm{Cp}_{2} \mathrm{ZrMe}\right]^{+}$and $\left.\left[\mathrm{Cp}_{2} \mathrm{ZrO}\right]_{2}\right]^{+}$ions form. $\left[\mathrm{Cp}_{2} \mathrm{ZrO}_{2}\right]^{+}$largely parallels the behavior of $\left[\mathrm{Cp}_{2} \mathrm{ZrMe}\right]^{+}$, suggesting that the former is generated from the latter. The gas phase reactivity of $\left[\mathrm{Cp}_{2} \mathrm{ZrMe}\right]^{+}$is limited to the work published by Richardson et al. ${ }^{30-32}$ and other than comments about the hydrolytic sensitivity in the experimental sections there is no published work that discusses the reaction with $\mathrm{O}_{2}$. We decided to model the reaction of formation of $\left[\mathrm{Cp}_{2} \mathrm{ZrO}_{2}\right]^{+}$from $\left[\mathrm{Cp}_{2} \mathrm{ZrMe}\right]^{+}$in the gas phase computationally.

Conversion from $\left[\mathrm{Cp}_{2} \mathrm{ZrMe}\right]^{+}$to the oxidized species via a $\left[\mathrm{Cp}_{2} \mathrm{Zr}\right]^{+}$intermediate is energetically prohibitive, so we considered a concerted mechanism where $\mathrm{O}_{2}$ replaces the methyl group (Figure 9).



Figure 9: The $\left[\mathrm{Cp}_{2} \mathrm{ZrMe}\right]^{+}+\mathrm{O}_{2}$ reaction pathways calculated with SIESTA (UPBE-D2). The $\mathrm{Zr}$ ligand exchange is assisted by stabilizing the Me leaving group (TS 67).

However, reaction coordinate analysis through linear transit scans at $0 \mathrm{~K}$ identified a stable intermediate where $\mathrm{Zr}$ is bound to both $\mathrm{O}_{2}$ and $\mathrm{Me}$ (Int 6 in Figure 9), which was not observed 
experimentally. The gas phase calculations of the possible $\left[\mathrm{Cp}_{2} \mathrm{ZrMe}\right]^{+}+\mathrm{O}_{2} \rightarrow\left[\mathrm{Cp}_{2} \mathrm{ZrO}_{2}\right]^{+}+\mathrm{Me}$. reaction via a concerted mechanism found that the methyl radical was too reactive to present as an independent leaving group. Instead, the metal center accommodated both ligands as $\left[\mathrm{Cp}_{2} \mathrm{ZrMeO}_{2}\right]^{+}$, an intermediate species that is not observed in the mass spectra. Instead, $\left[\mathrm{Cp}_{2} \mathrm{ZrO}_{2}\right]^{+}$is observed directly in the experiment, suggesting that the methyl group has to leave through a stabilized pathway, such as by attaching to a scavenging group. Gas phase scavenging reactions have been observed in MS previously. ${ }^{36,37} \mathrm{Ab}$ initio molecular dynamics calculations of the reactions between $\left[\mathrm{Cp}_{2} \mathrm{ZrMeO}_{2}\right]^{+}$and possible scavengers were carried out at the PBE-vdwTS/DZP level in SIESTA, at a temperature of $300 \mathrm{~K}$, for $2 \mathrm{ps}$. Fluorobenzene (solvent), $\mathrm{N}_{2}$ and $\mathrm{O}_{2}$ (present in the desolvation gas) being the only species present in abundance during the transfer from solution phase to the high vacuum of the mass spectrometer were all considered as scavenger candidates. Fluorobenzene and $\mathrm{N}_{2}$ are inert to the $\left[\mathrm{Cp}_{2} \mathrm{Zr}\left(\mathrm{O}_{2}\right) \mathrm{Me}\right]^{+}$complex but $\mathrm{O}_{2}$ facilitates the removal of the methyl radical (see $\mathrm{SI}$ FB_Zr.MOV and O2_Zr.MOV) and formation of $\left[\mathrm{Cp}_{2} \mathrm{ZrO}_{2}\right]^{+}$.

Like the Ti complex, $\mathrm{O}_{2}$ as a side-on ligand is more favorable than end-on. From $\mathrm{MO}$ diagrams (Figure 10), we can make a qualitative argument that this is due to favorable overlap from $p_{x}$ and $\mathrm{p}_{z}$ orbitals in the two highest occupied molecular orbitals (HOMOs) in the side-on conformation. The end-on binding mode provides the $\mathrm{Zr}$ center overlap with the $\mathrm{p}_{z}$ and $\mathrm{p}_{\mathrm{y}}$ from one oxygen.

a



b

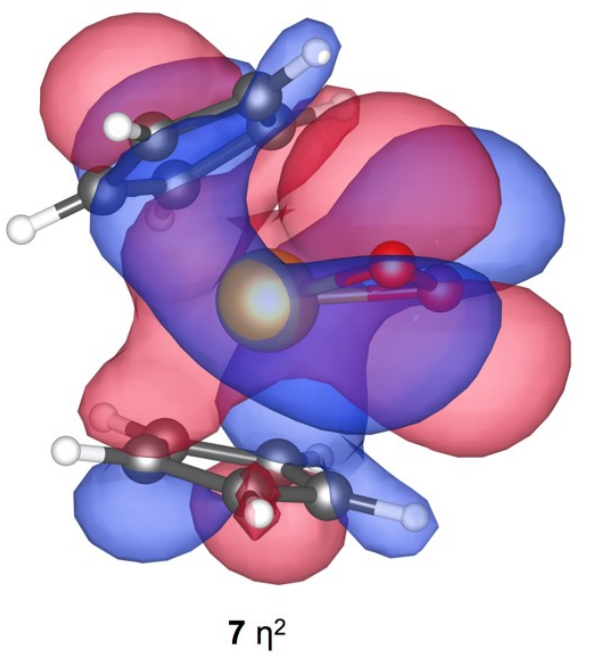

Figure 10. Highest occupied molecular orbitals of the zirconocene complexes: (a) and (b) show $\mathrm{HOMO}$ for monodentate and bidentate-bound $\mathrm{O}_{2}$ in $\left[\mathrm{Cp}_{2} \mathrm{ZrO}_{2}\right]^{+}$.

\section{Experimental Section}


General Considerations. All experiments were performed under an inert atmosphere using standard Schlenk and glovebox techniques. Acetonitrile and methanol (reagent grade, Fisher Chemical) were dried over $\mathrm{CaH}_{2}$ and distilled prior to use. Fluorobenzene (Oakwood) was refluxed over $\mathrm{CaH}_{2}$, distilled under $\mathrm{N}_{2}$, and dried over molecular sieves inside a glovebox for at least 3 days prior to use. $\mathrm{Me}_{3} \mathrm{Al}$ (2 $\mathrm{M}$ in toluene) was purchased from Sigma-Aldrich and used as received. $\mathrm{Cp}_{2} \mathrm{TiCl}_{2}$ (Sigma-Aldrich) and zinc dust (325 mesh, Anachemia) were used without further purification. $\mathrm{Cp}_{2} \mathrm{ZrMe}_{2}$ was purchased from Strem Chemicals and was used as received. $\left[\mathrm{Ph}_{3} \mathrm{C}\right]\left[\mathrm{B}\left(\mathrm{C}_{6} \mathrm{~F}_{5}\right)_{4}\right]$ was donated by Nova Chemicals Ltd. and recrystallized before use. $\left[\mathrm{Ph}_{3} \mathrm{PNPPh}_{3}\right]\left[\mathrm{PPh}_{2}\left(\mathrm{~m}-\mathrm{C}_{6} \mathrm{H}_{4} \mathrm{SO}_{3}\right)\right]$ was prepared using literature procedures. ${ }^{38,39}$ Polypropylene syringe filters ( $0.45 \mu \mathrm{m}$, Whatman) were dried prior to use in a vacuum oven.

All mass spectra were collected on a Micromass Q-ToF Micro mass spectrometer in negative mode (for phosphines) and positive mode (for titanocene and zirconium), using electrospray ionization. Capillary voltage was set at $3000 \mathrm{~V}$ with source and desolvation gas temperature at $85^{\circ} \mathrm{C}$ and $185^{\circ} \mathrm{C}$, respectively with the desolvation gas flow at $400 \mathrm{~L} \mathrm{~h}^{-1}$. MS/MS data were obtained as product ion spectra using 5.0 grade argon as the collision gas and a voltage range of 2-100 V.

Nitrogen for desolvation and cone gas was supplied from cylinders (4.0 and 5.0 grades were purchased from Praxair) or using a Genius 1053 nitrogen generator, purchased from Peak Scientific. Both the cylinders and the generator were connected to three different mass spectrometers via a common gas manifold with manual switching capability between the two sources using two ball valves. In experiments featuring variable $\mathrm{N}_{2}$ flow rates, constant desolvation and cone gas settings were established at the Q-ToF Micro instrument while flow settings at another instrument were adjusted to increase total $\mathrm{N}_{2}$ flow from the generator.

\section{Analysis of Phosphine Oxidation using $\left[\mathrm{N}\left(\mathrm{PPh}_{3}\right)_{2}\right]\left[\mathrm{PPh}_{2}\left(m-\mathrm{C}_{6} \mathrm{H}_{4} \mathrm{SO}_{3}\right)\right]$ and $\mathrm{Pd}\left(\mathrm{PPh}_{3}\right)_{4}$}

$\left[\mathrm{Ph}_{3} \mathrm{PNPPh}_{3}\right]\left[\mathrm{PPh}_{2}\left(\mathrm{~m}-\mathrm{C}_{6} \mathrm{H}_{4} \mathrm{SO}_{3}\right)\right](0.0100 \mathrm{~g}, 11.2 \mu \mathrm{mol})$ was dissolved in methanol $(7 \mathrm{~mL})$ in a Schlenk flask under $\mathrm{N}_{2}$. $\mathrm{Pd}\left(\mathrm{PPh}_{3}\right)_{4}(0.0052 \mathrm{~g}, 4.5 \mu \mathrm{mol} ; 40 \%$ loading) was suspended in methanol $(3 \mathrm{~mL})$ and added by syringe to the stirred phosphine solution. The resulting solution was injected from the glove box to the spectrometer via PTFE tubing (1/16" o.d., $0.005^{\prime \prime}$ i.d.). The results are provided as Supporting Information.

\section{Analysis of $\left[\mathrm{Cp}_{2} \mathrm{Ti}\left(\mathrm{NCCH}_{3}\right)_{2}\right]\left[\mathrm{ZnCl}_{3}\right]$}

Preparation of $\left[\mathrm{Cp}_{2} \mathrm{Ti}\left(\mathrm{NCCH}_{3}\right)_{2}\right]^{+}$was done using a previously published procedure. ${ }^{16} \mathrm{Cp}_{2} \mathrm{TiCl}_{2}$ (32 $\mathrm{mg}, 0.13 \mathrm{mmol}$ ) was dissolved in $60 \mathrm{~mL}$ acetonitrile. Zinc dust $(2 \mathrm{~g}, 30.6 \mathrm{mmol})$ was added and the solution stirred for 2 days. Filtration gave a blue solution of $\left[\mathrm{Cp}_{2} \mathrm{Ti}\left(\mathrm{NCCH}_{3}\right)_{2}\right]^{+}$, which was injected from the glove box to the spectrometer via PTFE tubing (1/16" o.d., $0.005^{\prime \prime}$ i.d.) at a rate of $40 \mu \mathrm{L} / \mathrm{min}$.

\section{Analysis of $\left[\mathrm{Cp}_{2} \mathrm{ZrMe}_{2} \mathrm{AlMe} \mathrm{H}_{2}\right]\left[\mathrm{B}\left(\mathrm{C}_{6} \mathrm{~F}_{5}\right)_{4}\right]$}


Trityl tetrakis(pentafluorophenyl)borate, $\left[\mathrm{Ph}_{3} \mathrm{C}\right]\left[\mathrm{B}\left(\mathrm{C}_{6} \mathrm{~F}_{5}\right)_{4}\right]$ (36 mg, $\left.39.0 \mu \mathrm{mol}\right)$ was weighed out and dissolved in fluorobenzene $(5 \mathrm{~mL})$. In a separate vial, $10 \mathrm{mg}$ of $\mathrm{Cp}_{2} \mathrm{ZrMe}_{2}(40 \mu \mathrm{mol})$ was dissolved in fluorobenzene $(5 \mathrm{~mL})$. To this $0.2 \mathrm{~mL}$ of $\mathrm{AlMe}_{3}$ solution (10 equiv.) was added. Finally $0.2 \mathrm{~mL}$ of the $\left[\mathrm{Ph}_{3} \mathrm{C}\right]\left[\mathrm{B}\left(\mathrm{C}_{6} \mathrm{~F}_{5}\right)_{4}\right]$ stock solution was further diluted to $5 \mathrm{~mL}$ and $0.2 \mathrm{~mL}$ of $\mathrm{Cp}_{2} \mathrm{ZrMe} / \mathrm{Me}_{3} \mathrm{Al}$ solution was added dropwise by syringe with stirring. The resulting colorless solution of $\left[\mathrm{Cp}_{2} Z \mathrm{ZMe}_{2} \mathrm{AIMe} \mathrm{M}_{2}\right]\left[\mathrm{B}\left(\mathrm{C}_{6} \mathrm{~F}_{5}\right)_{4}\right]$ and excess $\mathrm{Me}_{3} \mathrm{Al}$ was injected from the glove box to the spectrometer via PTFE tubing (1/16" o.d., 0.005" i.d.) at a rate of $40 \mu \mathrm{L} / \mathrm{min}$. Once the total ion chronogram had stabilized, cone voltages were adjusted to generate the $m / z 235$ ion (and its hydrolysis or oxidation products) in the gas phase (cone voltage typically 16-24 V).

\section{Computations}

Reaction paths for the oxidation of $\left[\mathrm{Cp}_{2} \mathrm{Ti}\left(\mathrm{CH}_{3} \mathrm{CN}\right)_{2}\right]^{+}$and $\left[\mathrm{Cp}_{2} \mathrm{ZrMe}\right]^{+}$were estimated a series of DFT functionals in the SIESTA 4.0.1 and ORCA 4.0 codes. ${ }^{40,41} \mathrm{~A}$ spin-polarized UPBE/DZP formalism was used in SIESTA, with Troullier-Martins norm-conserving pseudopotentials, and dispersive interactions included at the D2 level of Grimme, which is appropriate for gas -phase metal species. ${ }^{42,43}$ The effects of Hartree-Fock exchange and basis set size were considered by using a series of unrestricted methods available in the ORCA software. Single point energies for SIESTA-optimized ground and transition state structures were confirmed using UPBEO/TZVP, UPBE0-D2/TZVP, UPBE0-D3/TZVP, and RI-UB2PLYP-D3/TZVP in ORCA (SI, Table 1). The structural convergence of relevant, stable Ti complexes was confirmed by comparison to RIUB2PLYP-D3/TZVP-level calculations in ORCA. Given the agreement between SIESTA-based UPBE/DZP calculations and ORCA-based RI-UB2PLYP-D3/TZVP, all Zr calculations were performed in SIESTA.

Transition states were estimated using relaxed scans (linear transit) in SIESTA, using a homemade Python script that reduced and fixed the distance between an oxygen molecule and the metal complex. Methyl groups are quite energetic, so the presence of possible methylscavenging molecules $\left(\mathrm{O}_{2}, \mathrm{~N}_{2}\right.$, methyl radical) was also considered in the case of $\left[\mathrm{Cp}_{2} \mathrm{ZrMe}\right]^{+}$ oxidation. Additional ab initio molecular dynamics (AIMD) calculations were performed in SIESTA at the PBE/DZP level, to follow the behavior of the complexes under ambient temperature conditions. The AIMD procedure in SIESTA used a Nose-Hoover thermostat ramping from 0 to $300 \mathrm{~K}$, with 1 fs timestep. Between 500 and 1000 timesteps were considered, until the simulation completed. All SIESTA calculations used a pseudo-atomic orbital (PAO) confinement energy of $1 \mathrm{mRy} .{ }^{44}$

\section{Conclusions}

For most applications in electrospray ionization mass spectrometry, nitrogen generators eliminate enough oxygen that spectra are indistinguishable from high purity sources of nitrogen. Only the most reactive ions generate byproduct ions attributable to gas-phase oxygenation, and in the case of an indicator developed for detection of $\mathrm{O}_{2},{ }^{14,15}$ the extent of oxidation is $<10 \%$ (see Figure 1). On the other hand, extremely reactive ions such as the 14 e $\left[\mathrm{Cp}_{2} \mathrm{ZrMe}\right]^{+}$are much 
more reactive towards oxygen and water; using such ions as probes, the source(s) of contamination within the spectrometer can be readily discovered and corrected for as in the present work.

\section{Acknowledgements}

We thank NOVA Chemicals' Centre for Applied Research for financial support. J. S. M. thanks NSERC (Strategic Project Grant \#478998-15) for operational funding and CFI, BCKDF, and the University of Victoria for infrastructural support. S. C. acknowledges support for a Visiting Scientist position from the University of Victoria

\section{References}

1 R. G. Belli, Y. Wu, H. Ji, A. Joshi, L. P. E. Yunker, J. S. Mclndoe and L. Rosenberg, Inorg. Chem., , DOI:10.1021/acs.inorgchem.8b02915.

2 L. P. E. Yunker, Z. Ahmadi, J. R. Logan, W. Wu, T. Li, A. Martindale, A. G. Oliver and J. S. Mclndoe, Organometallics, 2018, 37, 4297-4308.

3 G. T. Thomas, E. Janusson, H. S. Zijlstra and J. S. Mclndoe, , DOI:10.26434/CHEMRXIV.8345594.V1.

4 T. K. Trefz, M. A. Henderson, M. Linnolahti, S. Collins and J. S. Mclndoe, Chem. - A Eur. J., 2015, 21, 2980-2991.

5 A. T. Lubben, J. S. McIndoe and A. S. Weller, Organometallics, 2008, 27, 3303-3306.

6 W. Henderson, J. S. McIndoe and John Wiley \& Sons., Mass spectrometry of inorganic, coordination, and organometallic compounds, J. Wiley, 2005.

7 T. Guo, R. L. Taylor, R. J. Singh and S. J. Soldin, Clin. Chim. Acta, 2006, 372, 76-82.

8 A. I. Shirley and N. O. Lemcoff, AIChE J., 1997, 43, 419-424.

9 D. M. Chisholm, A. G. Oliver and J. S. Mclndoe, Dalt. Trans., 2010, 39, 364-373.

10 A. V. Hesketh, S. Nowicki, K. Baxter, R. L. Stoddard and J. S. Mclndoe, Organometallics, 2015, 34, 3816-3819.

11 M. A. Henderson, T. K. Trefz, S. Collins, M. Y. Wang and J. S. Mclndoe, Organometallics, 2013, 32, 2079-2083.

12 H. S. Zijlstra, S. Collins and J. S. McIndoe, Chem. - A Eur. J., , DOI:10.1002/chem.201705458.

13 T. K. Trefz, M. A. Henderson, M. Y. Wang, S. Collins and J. S. Mclndoe, Organometallics, 2013, 32, 3149-3152.

14 S. Collins, M. Linnolahti, M. G. Zamora, H. S. Zijlstra, M. T. Rodríguez Hernández and O. Perez-Camacho, Macromolecules, 2017, 50, 8871-8884. 
S. J. N. Burgmayer, J. Chem. Educ., 1998, 75, 460.

D. Yeung, J. Penafiel, H. S. Zijlstra and J. S. McIndoe, Inorg. Chem., , DOI:10.1021/acs.inorgchem.7b02705.

17 T. E. Barder and S. L. Buchwald, J. Am. Chem. Soc., 2007, 129, 5096-5101.

18 A. Sen and J. Halpern, J. Am. Chem. Soc., 1977, 99, 8337-8339.

19 V. V. Grushin, Organometallics, 2001, 20, 3950-3961.

20 J. P. Birk, J. Halpern and A. L. Pickard, J. Am. Chem. Soc., 1968, 90, 4491-4492.

21 J. Halpern and A. L. Pickard, Inorg. Chem., 1970, 9, 2798-2800.

22 K. L. Vikse, M. P. Woods and J. S. McIndoe, Organometallics, 2010, 29, 6615-6618.

23 H. Aneetha, M. Jiménez-Tenorio, M. C. Puerta, P. Valerga and K. Mereiter, Organometallics, 2002, 21, 628-635.

24 S. Collins, Unpublsihed Work.

25 A. Schulte-Schulze-Berndt and K. Krabiell, Gas Sep. Purif., 1993, 7, 253-257.

26 Genius 1053 - Nitrogen gas generator, https://www.peakscientific.com/products/genius/genius-1053-nitrogen-generator, (accessed 9 February 2020).

27 T. K. Woo, P. M. Margl, L. Deng, L. Cavallo and T. Ziegler, Catal. Today, 1999, 50, 479-500.

28 M. Bochmann and S. J. Lancaster, Angew. Chemie Int. Ed. English, 1994, 33, 1634-1637.

29 M. Bochmann, A. J. Jagger and J. C. Nicholls, Angew. Chemie Int. Ed. English, 1990, 29, 780-782.

30 C. S. Christ, J. R. Eyler and D. E. Richardson, J. Am. Chem. Soc., 1990, 112, 596-607.

31 C. S. Christ, J. R. Eyler and D. E. Richardson, J. Am. Chem. Soc., 1990, 112, 4778-4787.

32 C. S. Christ, J. R. Eyler and D. E. Richardson, J. Am. Chem. Soc., 1988, 110, 4038-4039.

33 D. Feichtinger, D. A. Plattner and P. Chen, J. Am. Chem. Soc., 1998, 120, 7125-7126.

34 J. A. Labinger, D. W. Hart, W. E. Seibert and J. Schwartz, J. Am. Chem. Soc., 1975, 97, 3851-3852.

35 M. Vatamanu, J. Catal., 2015, 323, 112-120.

36 C. K. Barlow, A. Wright, C. J. Easton and R. A. J. O'Hair, Org. Biomol. Chem., 2011, 9, 37333745.

37 O. Böge, A. Mutzel, Y. linuma, P. Yli-Pirilä, A. Kahnt, J. Joutsensaari and H. Herrmann, Atmos. Environ., 2013, 79, 553-560.

38 M. R. Barton, Y. Zhang and J. D. Atwood, J. Coord. Chem., 2002, 55, 969-983.

39 K. L. Vikse, M. A. Henderson, A. G. Oliver and J. S. McIndoe, Chem. Commun., 2010, 46, 7412-7414. 
40 J. M. Soler, E. Artacho, J. D. Gale, A. García, J. Junquera, P. Ordejón and D. Sánchez-Portal, J. Phys. Condens. Matter, 2002, 14, 2745-2779.

41 F. Neese, WIREs Comput. Mol. Sci., 2012, 2, 73-78.

42 S. Grimme, J. Comput. Chem., 2006, 27, 1787-1799.

43 A. Tkatchenko and M. Scheffler, Phys. Rev. Lett., 2009, 102, 073005.

44 C. R. L. Chapman, E. C. M. Ting, A. Kereszti and I. Paci, J. Phys. Chem. C, 2013, 117, 1942619435. 